\title{
A spatio-legal approach to the intermediate housing-with-care solutions for older people: exploring the adoption of a retirement village concept in Finland
}

\author{
Riina Lundman ${ }^{1 \star}$ \\ ${ }^{1}$ Department of Geography and Geology, University of Turku, Turku, Finland \\ ${ }^{*}$ Corresponding author. Email: riina.lundman@utu.fi
}

(Accepted 13 March 2019; first published online 11 April 2019)

\begin{abstract}
Retirement villages are an increasingly popular senior housing option that aims to comprehensively integrate accommodation, care services, social activities and interaction opportunities for ageing people. The research literature about retirement villages and communities is extensive, but less studied are the contextually varying spatial, legal and political processes of how such villages and other intermediate housing-with-care solutions for older people are initially constituted, especially in novel national and local contexts. In this paper, a spatio-legal approach is employed to study the many legal possibilities and barriers that have arisen while developing retirement villages in Finland. As a specific case, I examine the new Finnish Virkkulankylä retirement village concept and its implementation process. As the key result of my study, I identify three major spatio-legal barriers to developing retirement villages and other intermediate senior housing solutions, which are (a) the polarised division between the fields of elderly care and housing in both law and practice, (b) the prevalence of 'local law' in spatial planning and service provision for elderly people, and (c) the inflexible funding system regarding alternative housing-with-care solutions for seniors. I argue that although the 'in-betweenness' of retirement villages may facilitate a more comprehensive understanding about the housing and care of older adults, in practice their intermediary position translates into many ambiguities and challenges.
\end{abstract}

Keywords: retirement villages; housing-with-care; senior housing; spatio-legal approach; Finland

\section{Introduction}

In many Western countries, the sites and settings of elderly care have been increasingly deinstitutionalised and shifted from institutional facilities to homes and community-based care environments (Milligan, 2009). Retirement villages, in particular, seem to represent new and alternative living solutions, as they aim to offer combined housing and care services as well as social activities and interaction 
opportunities for ageing people (Croucher, 2006; Scharlach et al., 2014). Increasingly popular in various geographical and policy settings, retirement villages seek to serve as intermediate or 'third-way' options as they are situated in-between institutional care settings and home spaces (Evans, 2009a). In the United States of America (USA), Australia and the United Kingdom (UK), for instance, retirement villages and communities are relatively established living models for senior citizens, and the research literature about them is already quite extensive (e.g. Streib, 2002; Bernard et al., 2007, 2012; Evans, 2009b; Liddle et al., 2014; Scharlach et al., 2014; Xia et al., 2015; Holland et al., 2017). However, this research is mostly Anglocentric (Howe et al., 2013), and much less has been written about the situation in other countries where the retirement village concept has been more recently adopted. Moreover, the existing research literature is less focused on the contextually varying spatial, legal and political processes of how the retirement villages and other intermediate housing-with-care models are initially created and constituted. This research gap calls for attention, especially because developing new housing solutions for older people can involve many problems and controversies. As demonstrated in this paper, some of these challenges are related to practical issues concerning the planning, funding and management of such projects. Other challenges concern more critical aspects such as the age-segregation of retirement communities (Laws 1993; Townshend, 2002), the unequal access to them (Petersen et al., 2017) and the commodification of elderly care (Cutchin, 2007; Green and Lawson, 2011). In this article, I primarily examine the practical problems regarding the development of retirement villages, but in several sections I also touch upon the more controversial features and ambiguities of the new forms of senior housing. For analysis, I employ a spatio-legal approach to study how the law, space and local practices operate in the creation of retirement villages, especially when their development occurs in novel national and local contexts.

Although retirement village models have gained wide international popularity, their adoption in different locations does not always unfold without problems. My study is conducted in Finland, where purpose-built retirement villages are a relatively new phenomenon, and some prototype facilities are only recently emerging following a wider restructuring of the care services for older people. Similar to other former welfare regimes in the Nordic countries, Finland has relied heavily on public services for elderly care (see Paasivaara, 2002). However, there is now strong political and legislative pressure in Finland to reorganise elderly care policies and housing arrangements in the name of public fiscal sustainability, an ageing population and the so-called 'retirement bomb'. In this article, I am particularly interested in how new and alternative housing-with-care solutions for older people, including retirement villages, are constituted, supported and restricted by Finnish laws, policies, regulations and administrative practices. As a specific case, I examine the brand Virkkulankylä ('Frisky Village'), which is a new - but not necessarily that alternative - housing and living concept for ageing people that a private property development company has established in various locations around Finland. In particular, I discuss how the Virkkulankylä concept abundantly demonstrates the many ambiguities that establishing an intermediate housing-with-care model in a new context may confront, especially when the law and other bureaucratic practices do not yet fully identify or acknowledge the 'third-way' housing solutions that retirement villages represent. 
Theoretically and methodologically, this study belongs to the field of legal geography where one key interest is investigating the ways in which the law 'happens' and materialises as a part of space (Delaney, 2010; Braverman et al., 2014). I start this paper with a general discussion concerning the changing landscapes of elderly care ( $c f$. Milligan, 2000; Milligan and Wiles, 2010) and how retirement villages have arisen as an answer to the wider politics of 'ageing-in-place' in many countries. I also examine some existing literature about the benefits and problems of the retirement village model. In the empirical part of this paper, I analyse several Finnish laws, acts and policy documents concerning social services and the built environment, and study how the needs and the obstacles of intermediate housing-with-care solutions for ageing people are created in these official texts. Thus, I am interested in what kinds of legal possibilities, (dis)incentives and barriers exist for the development of retirement villages in Finland. As a practical example, I study the planning and implementation processes behind the Virkkulankylä village concept to understand the complex relationship between law and spatial practices. Finally, I present my findings as a spatio-legal interpretation of intermediate housing-with-care solutions and specify the main challenges and potentials related to their development. As the key result of my study, I identify three major spatio-legal barriers regarding such solutions, which are (a) the polarised division between the fields of elderly care and housing in both law and practice, (b) the prevalence of the so-called 'local law' in providing and governing spatial planning and services for elderly people, and (c) the inflexibility of the statutory funding systems regarding alternative housing-with-care solutions for seniors. I argue that even though the 'in-betweenness' of the retirement villages is an asset for understanding the alternative living options for older people, in practice their intermediary location between the categories of homes and institutions as well as housing and care translates into many legal and practical challenges. Flexibility, horizontal thinking and collaboration are some solutions for overcoming these challenges.

\section{Retirement villages and their place in the changing landscapes of elderly care}

Retirement villages as intermediate housing-with-care solutions for ageing adults

Much of the discussion around the current and future situations of older people is concerned with where ageing citizens should be housed and cared for; that is, whether elderly people who need care, support and social services should live and stay in institutional settings, in their own homes or somewhere else (Andrews and Phillips, 2004; Evans, 2009a; Milligan, 2009). During the last few decades, the idea of 'ageing-in-place', referring to living in the community rather than in an institutional setting (Wiles et al., 2011: 357), has gained prominence in the political agendas of many countries as part of the wider deinstitutionalisation of elderly care (see Milligan, 2009). Retirement villages and communities, along with other alternative housing models that combine accommodation with care and social activities, correspond well to this emphasis on the community-based living of older people. These new senior housing solutions often have the potential for being age-friendlier and safer settings for older citizens than normal home 
environments (Croucher, 2006; Liddle et al., 2014; Scharlach et al., 2014) and, at the same time, the residents are afforded more independence than in traditional nursing homes or residential care settings. For example, Croucher (2006: 1) commends retirement villages as estates that provide ageing residents with 'purpose-designed barrier-free housing ... a range of facilities and activities that are not care related [but] generate opportunities for informal and formal social activity ... [and] a range of care and support services that can respond quickly and flexibly to a range of care needs over time'. More simply, retirement villages are promoted as 'housing with care for later life' (Croucher et al., 2006) where the social and experiential sides of ageing are appreciated.

Hence, retirement villages represent one form of 'service integrated housing', a general term referring to the wide range of combined housing and care solutions for older people (Howe et al., 2013). The definitions and characteristics of retirement villages vary in different countries, and therefore a comparison between different village models can be difficult (for international perspectives, see Evans, 2009a; Howe et al., 2013). For example, in Australia, New Zealand and, more recently, the UK, retirement villages have become relatively common concepts that usually refer to living solutions that integrate accommodation, care, activities and support services for ageing people in a limited geographical area, community or location (Croucher, 2006). In the USA, purpose-built retirement communities and resorts are usually more leisure and lifestyle-oriented housing estates that can be quite expensive and luxurious; yet there exist also more affordable housing-with-care models and continuous care retirement communities in the USA (see Howe et al., 2013; Scharlach et al., 2014). In the Netherlands, Germany and Denmark, there are special villages designed and built for the needs of dementia patients and other people with memory disorders (Glass, 2014; Haeusermann, 2018; Svendborg, 2018). In Finland, the concept of the retirement village is still relatively new, and therefore I use the term 'intermediate housing-with-care' as an umbrella concept for all kinds of alternative and integrated senior housing models that bear similarities with the international village models. Overall, the spectrum of retirement villages and communities is wide and so are the spatial contexts and outcomes in which they appear. What is crucial for this study is to understand the specific role of retirement villages as in-between living arrangements for older adults. They integrate the elements of housing and care but cannot be clearly considered as domestic or institutional environments ( $c f$. Evans, 2009a); or in other words, they involve characteristics of home-spaces and institutions but are not exclusively either.

\section{The possibilities and problems of retirement villages}

As the terms already suggest, the residents of retirement villages and communities are usually retired or close to retirement age, and they may have various needs and expectations regarding elderly care and support services. The villages provide residents with barrier-free housing and care, and thus they seek to offer secure living environments that simultaneously maintain and promote senior citizens' independence (Croucher, 2006). Regarding the social aspects, the village model usually aims to enhance the social engagement of its members and allows them to interact with 
the surrounding community by offering services also to non-members (Scharlach et al., 2014). From a more critical perspective, purpose-built retirement villages and communities can be seen to form age-segregated and gated communities (Laws 1993; Townshend, 2002; Bernard et al., 2012) where the level of integration with the rest of the society is not always self-evident. Moreover, as the study conducted by Bernard et al. (2007) shows, the mix of frail and fit older people in the same facilities can lead to tensions, exclusions and feelings of isolation among some residents. Some people may need to move away from the retirement villages and communities when they get frailer and older, which can be disturbing for ageing residents and can cause notions of uncertainty, liminality and anxiety ( $c f$. Frank, 2001). Hence, retirement villages and other such intermediate housing-with-care settings do not necessarily offer a permanent living option for later life but only what Frank (2001: 6) calls a 'prolonged residence' for relatively fit older adults.

Another important critique of retirement villages, which also impinges on the provision of services for elderly people in a wider sense, is the commodification and marketisation of care (Cutchin, 2007; Green and Lawson, 2011; Schwiter et al., 2018). As pointed out by Green and Lawson (2011: 646), framing care as a purchasable commodity does not necessarily consider the relational aspects of human life, which may lead to 'care without caring' (see also Repo, 2018) and to neglecting the real needs of people living in elderly care facilities (Cutchin, 2007). The lifestyle-oriented retirement communities, especially, are seen to represent complex landscapes of consumerism, simulation and fragmented identities (Laws, 1995). Commodified care is closely related to the privatisation of social and health-care services. Privately owned and priced housing-with-care solutions are often more expensive than the public ones, which creates an unequal access to such settings (Hoppania et al., 2016).

At the same time, there are also many studies that present positive aspects of living in retirement villages and communities. These studies have shown, for example, that new residents may gain psychological benefits and improve functional limitations when moving into a retirement village (Holland et al., 2017), and that the sense of community and belonging can be strong among some residents (although far from cohesive; see Evans, 2009b; Bernard et al., 2012). Moreover, thoughtfully designed facilities can reduce the anxiety of residents suffering from dementia and other memory disorders (Glass, 2014; see also Chrysikou et al., 2018). Some new funding opportunities and mixed-tenure systems have been developed to make retirement villages and new senior housing options more available also for less-affluent residents (Evans, 2009b; Jalava et al., 2017). In the larger view, retirement villages and other alternative housing-with-care arrangements can diversify accommodation and care options for older people, which, as stated by Pynoos (2018: 37), may create non-conventional living solutions that will 'better meet the diverse needs and lifestyles of older persons'. Therefore, the adoption of a retirement village model can resolve the micro-level and macro-level demands related to the ageing population and their wellbeing. Yet, due to the many ambiguities related to such models, more research is required about the planning and implementation of retirement villages and other similar housing-with-care solutions. 


\section{Finland: the context}

Before analysing Finnish legislation, I briefly describe the political context and background regarding the development of elderly care services and new senior housing solutions in Finland. As in other Western societies, the Finnish landscape of elderly care has changed extensively within the past decades (e.g. Paasivaara, 2002; Anttonen and Häikiö, 2011). The shift from a welfare state to a neoliberalised competition society has occurred here later than in many other Western European countries (Moisio, 2012), and therefore the deinstitutionalisation and privatisation of elderly care services has been a relatively recent and rapid phenomenon in Finland (THL, 2011, 2017). During recent years, many publicly owned traditional nursing homes have been converted into service fee-based (and often private) sheltered housing or extra-care housing units (Hoppania, 2015; THL, 2017). In addition, the current Finnish Government emphasises home-based care as the primary accommodation and service solution for the older population (STM, 2016). There are multiple rationales for favouring private social services and homebased care for elderly people, including the wider neoliberalisation of the whole society, the political and economic goals of cutting the public cost of institutional care, and the presumed aspiration of older people to live in their own homes (see Evans, 2009a; Milligan, 2009; Hoppania, 2015).

However, both the extra-care housing and home-based care of older people have lately received negative exposure in Finland for various reasons, such as a lack of resources, bad care and claims about the abandonment of frail old people in their homes (e.g. Parliamentary Ombudsman, 2009; Jylhä, 2015; Valvira, 2016; Kröger et al., 2018). The call for more diversified and age-friendly living and care environments for elderly people has been recognised, and, to some extent, encouraged by public and private actors. The result has been the development of new initiatives that intend to offer more alternative and intermediate options for the care and accommodation of ageing people. These new housing-with-care solutions are many, and they include various kinds of senior apartments, family care residences, co-housing projects, as well as multiservice blocks and intergenerational service blocks (Jolanki and Kröger, 2015; Pirinen, 2016; Jalava et al., 2017; Verma et al., 2017). Retirement villages and communities are also among the suggested solutions for community-based living for ageing adults (e.g. Jolanki and Kröger, 2015: 87; Jalava et al., 2017: 18-19). All these intermediate senior housing options espouse the deinstitutionalisation of elderly care, but still seek to guarantee an adequate level of services for older people. In practice, however, the legislative, administrative and economic tools that would promote the concrete development of retirement villages and other intermediate housing-with-care forms for older people remain vague in Finland, as is demonstrated in this paper.

\section{Research material and analysis}

The following empirical part of this article is divided into two parts. First, I study Finnish law and other official regulations, and consider the legal framework they impose on retirement villages and other intermediate housing-with-care solutions. I examine key Finnish legislation concerning, for example, social and elderly care services, land use planning and state-subsidised housing, as well as different policy 
documents, reports and technical guidelines produced by various governmental bodies and other organisations. My approach is spatio-legal as I focus on the parts of laws and policies that emphasise the spatial aspects regarding the care and living of older people. I have analysed the texts systematically by reading, coding, categorising and evaluating them according to how they deal with the spatialities of older people and their living conditions (for the method, see Bowen, 2009; Cope, 2010), and especially how intermediate housing-with-care options are treated in these documents.

The second part of the empirical work in this paper concerns the Virkkulankylä retirement village concept now being developed in different locations in Finland. With respect to Virkkulankylä, the main research material consists mostly of textual data (Documents 1-12; see the Appendix for details). In addition, I have undertaken four semi-structured interviews with key persons working with the Virkkulankylä concept to gain additional information about the project's background (Interviews 1-4, see the Appendix for details). As part of my research, I also visited one Virkkulankylä (in Reijola, eastern Finland), which was the only fully functional Virkkulankylä at the time of my study. However, the Virkkulankylä in Reijola proved to be more like a conventional extra-care housing unit of older people and less like the community-oriented village setting depicted in the original Virkkulankylä concept design. I use some of my field notes from this visit as research material because it was interesting to observe how the setting was not as alternative as expected in its form and function.

As previously mentioned, the analysis and interpretation of the research materials are based on the spatio-legal approach. This means that the investigated documents and legal statutes (the 'law') are not treated as neutral texts but are seen to impact spaces and places where they occur and vice versa (cf. Delaney, 2010; Braverman et al., 2014). Laws and policies, as well as their interpretations and practical implications, are not fixed or self-evident, but they involve various powerrelated issues and ambiguities; they are relational, as is the case with the spaces they constitute (Rannila, 2018; for the relationality of space, see Massey, 2005). Moreover, the law functions at different spatial levels. In addition to national law, there exists a wide set of local regulations and rules that Valverde (2012) calls 'local law', which has a strong effect on a community's social and spatial practices. Although I comprehend law, space and practices as deeply intertwined concepts, in the following legal and policy analysis I have made a binary division between statutes and policies that cover, firstly, social services and elderly care and, secondly, the built environment and housing questions. This distinction is made primarily for analytical purposes in order to scrutinise the law-related research material in this study; however, the division also indicates a deeply rooted gap between the care and housing sectors in Finland.

\section{Legal and policy analysis of Finnish legislation Social services and elderly care}

Despite the current deinstitutionalisation and privatisation of elderly care, the role of public authorities is still strong in organising, controlling and governing the care 
and housing services for older people in Finland. According to the Finnish Social Care Act (1301/2014), municipalities are obliged to provide housing and care for people who need special support and help with their living arrangements $(21 \S)$. The services in extra-care housing units, for instance, may include 'nursing and care services based on the needs of the client; ... dining, clothing, hygiene, and cleaning services; as well as services that promote the participation and social interaction of the client' $(21 \S) .{ }^{1}$ The municipalities can organise these services themselves, purchase them from other (often private) service providers or supply clients with service vouchers. In general, the legal context of social services in Finland offers a relatively equal and extensive basis for comprehensive housing and care solutions for the ageing population, including those of the retirement villages. In practice, however, the situation is more complex because the law can be interpreted and practised in various ways.

In the 2010s, there have been some major legislative changes concerning the social services for older people in Finland. An important reform is the so-called Elderly Service Act (Act on Supporting the Functional Capacity of the Older Population and on Social and Health Services for Older Persons 980/2012), which is the first Finnish law solely covering questions regarding the older population (Mäki-Petäjä-Leinonen and Karvonen-Kälkäjä, 2017). The objectives of the Act include supporting the wellbeing, health and independent living of the older population, as well as improving access to high-quality social and health-care services for older people (Elderly Service Act, $1 \S$ ). Hence, the Elderly Service Act mentions both the living conditions and good care of older people as important goals but nevertheless treats them as separate functions. This distinction is problematic for intermediate housing-with-care solutions where the aim is integrating housing and care services instead of separating them.

Moreover, the spatialities and spatial alternatives regarding elderly care settings are quite narrowly understood in Finnish law. A division has been made between homes, sheltered and extra-care housing units, and institutional care settings (such as nursing homes and hospital wards), but the more recent intermediate housing-with-care solutions for older people are practically absent from the Social Care Act and Elderly Service Act. The distinction between different care settings has become stricter in recent years. The original Elderly Service Act passed in 2012 declared that 'local authorities must organise long-term care and attention for older persons principally ... in the person's private home or another home-like place of residence' (Elderly Service Act, $14 \$$ , emphasis added). In 2014, this phrase was changed so that the word 'home-like' was removed (Act on Amending of the Act on Supporting the Functional Capacity of the Older Population and on Social and Health Services for Older Persons 1351/2014), indicating a stronger focus on home-based care ideologies. The right to residential care is not a subjective right of older people but is based on a separate assessment made by health-care and social service professionals (Elderly Service Act, $15 \S$ ). If a person is accepted into sheltered care or an extra-care facility, then the Act states that 'the service provider must see to it that the facilities ... are adequate, safe, accessible, homelike and even otherwise such that the conditions there are appropriate' (Elderly Service Act, 22 \$; see also Act on Private Social Services 922/2011, 4 \$). In terms of retirement villages, which are not clearly homes nor institutions, this kind of fixed division 
between home environments and residential care facilities can be challenging, especially if the residence is determined by public authorities and not by the older person themselves.

The Elderly Service Act further states that long-term elderly care

must be provided so that the older person can feel that he or she is living a safe, meaningful and dignified life and can maintain social contacts and participate in meaningful activities promoting and maintaining his or her wellbeing, health and functional capacity. (Elderly Service Act, $14 \$$ )

This particular provision offers a wider and more comprehensive understanding about the conditions of older people because it acknowledges the social and experiential aspects of human life and dignity. Therefore, this formulation fits well with the ideologies behind alternative housing-with-care solutions for ageing people, including those of retirement villages and communities. The Elderly Service Act, however, does not highlight any concrete measures or spatial solutions of how this kind of 'meaningful and dignified life' should be achieved (except for mentioning home spaces and home-based care). In the legislative drafts of the Elderly Service Act (HE 160/2012: 42) and its amendments (HE 240/2014: 11), ${ }^{2}$ some alternative and intermediate housing-with-care options are listed, including family care, informal care, senior group homes and home services. Apart from the group homes and, to some extent, family care residences, none of these examples are genuinely innovative housing solutions in spatial terms. Retirement villages or communities are not mentioned at all in these legislative drafts.

Regarding the quality of elderly care services, the Finnish Ministry of Social Affairs and Health (STM) has published a separate document called the Quality Recommendation to Guarantee a Good Quality of Life and Improved Services for Older Persons (STM, 2017). In the document, the possibilities for alternative housing-with-care models for older people are more clearly expressed than in the legislative texts. One concrete recommendation is that 'for the effective integration of housing and care, also new kinds of accessible, safe, supportive, and communitybased solutions are [to be] developed' (STM, 2017: 26). These solutions would encompass retirement villages, although they are not directly referred to in the text. However, the Quality Recommendation document is not a binding statute; it merely gives advice to decision makers and other actors in the field of elderly care services. Hence, the concrete impacts of the Quality Recommendations depend on how extensively and flexibly local authorities and care professionals apply the recommendations in their actual development work and care practices.

\section{Land use planning and the built environment}

The physical sites where the lives and care of older people take place are important for good ageing, and the development of such sites are often dependent on land use planning, zoning and housing policies (e.g. de Lisle 1998; Phoebe et al., 2006; Pynoos et al., 2008; Rosenthal, 2009; Pynoos, 2018). With respect to the built environment, the Finnish Ministry of the Environment (YM) has acknowledged the challenges and future needs of the ageing population and their living arrangements 
in Finland. During 2013-2017, the Ministry administered a Housing Development Programme for the Older Population (YM, 2013) that focused on the housing issues of ageing people and how they could be improved. Although the programme's first goal was to respond to the national objective regarding 'living at home' (YM, 2013: 6), it also specified the need for new housing models for older people. Land use planning, especially, was seen to have a pivotal role in steering the development of residential areas that would support the functional capacity of senior citizens and integrate the housing and services of various population groups (YM, 2013: 14). This integrated view on age-friendly and mixed living environments would also benefit the development of retirement villages and communities.

In the actual Finnish Land Use and Building Act (132/1999), however, only a few paragraphs directly guide the planning and zoning of age-friendly environments and integrated housing-with-care solutions. The needs of older people are explicitly mentioned in the Act a couple of times, for instance, when it states that 'the objective in land use planning is to promote ... a safe, healthy, pleasant, socially functional living and working environment which provides for the needs of various population groups, such as children, elderly people and people with disabilities' ( $5 \$$, emphasis added). In a separate document of the Finnish National Land Use Guidelines, the ageing population and their housing needs are referred to indirectly, as one of the guidelines is to '[c] reate capacities for the ... sufficient and diverse housing production required by demographic development' (YM, 2017: 6). Alternative or intermediate living solutions that combine housing, care and social activities in a flexible way are not mentioned separately in the Land Use Guidelines.

The Finnish land use planning and zoning system is based on a hierarchical structure where national guidelines direct regional plans that steer the local land use plans (see Land Use and Building Act 132/1999, chapters 3-7). At the most local level of the land use planning hierarchy (i.e. the local detailed plans), addressing the needs of various population groups is not specified as the statutory objective in the law. In terms of retirement villages, this is problematic because the local detailed plans establish the actual rules on what can be built and where. Due to the hierarchical planning system, the needs of older people are implicitly expected to be part of the local land use policies. However, concrete legislative incentives to advance age-friendly living environments are lacking or vague. Municipalities have a 'planning monopoly' in Finland (see e.g. Hytönen, 2016), so the decision of whether to build retirement villages or any other similar kinds of senior housing estates is left to municipal planning authorities and politicians.

The questions concerning the built landscape and new housing-with-care solutions become even more specific when the focus turns from land use planning to the design and architecture of the actual buildings and care settings. One way the Finnish Land Use and Building Act affects the age-friendliness of the society is through its provision about building accessibility (117 e $\$$ ). The Act requires that 'the building and its common areas are planned and built ... in a way that takes into consideration their accessibility and usability, especially relative to children, elderly people and people with disabilities' (117 e $\$$, emphasis added). This provision thus promotes barrier-free housing, which is one precondition for making purpose-built retirement villages (cf. Croucher, 2006). However, the 
understanding of 'accessibility' is limited because it focuses only on the technical side of the concept. An additional government decree details technical requirements and millimetre-precise instructions regarding the measures of building entrances, corridors, stairs, doors, and disabled toilets and bathrooms (see Government Decree on Building Accessibility 241/2017), but the social and experiential dimensions of building design and accessibility are given less attention.

Many of the planning guidelines concerning service integrated housing of older people are gathered in the commercial Building Information Card 93-11134 (Rakennustieto, 2013), which in many ways offers a broader view on integrating the built environment and the care needs of ageing people than the official building codes and decrees do. The Building Information Card starts with the notion that developing sheltered housing for elderly people is not only about planning new apartments but also about making design solutions that support the residents' physical and psychological wellbeing and increase their social capacity (Rakennustieto, 2013: 3). Similar to the law, the Building Information Card includes precise measurements for the buildings and built environment, but it also gives recommendations on such things as the comfort and homeliness of the common areas in age-related housing facilities, the attractive views from windows, the importance of peaceful dining areas, the provision of short-term accommodations for visitors, and the aesthetic features and functionality of gardens (Rakennustieto, 2013: 5-20). These elements involve a more comprehensive understanding of how the built, social and experiential spaces of elderly care and housing can be combined. At least in principle, the Building Information Card's specific design considerations are useful when developing retirement villages or any other alternative housing-with-care forms for older people.

Money, funding and resources are important incentives that guide the development of senior housing and care environments. The Housing Finance and Development Centre of Finland (ARA) issues grants and interest-subsidy loans to increase the provision of rental housing suitable for older people and other special groups (see Act on Subsidies for Improving the Housing Conditions of Special Groups 1281/2004). Although ARA grants and loans are statutory and governed by the state, the municipalities have an important role here because one precondition for the ARA grant is that local authorities are in favour of the potential housing project $(6 \S)$. ARA has its own guidelines and rules regarding project funding that need to be met before the grants and loans can be issued (see ARA, 2017). Some of these requirements are controversial with respect to the development of intermediate housing solutions for ageing people. For instance, the ARA grant can be targeted only for one special group at a time (ARA, 2017: 6), which prevents mixed groups of people living in one residence. Moreover, the grants and state loans are meant for rental housing only. Hence, the ARA funding is quite rigid with respect to intermediate housing-with-care solutions for ageing people, as the following example of the Virkkulankylä village concept also demonstrates. This rigidness further indicates the ambiguities between law and practices with respect to the development of alternative senior housing options in Finland. 


\section{Case: the Virkkulankylä retirement village}

An illustrative example of the new housing-with-care solutions for older people in Finland - and the opportunities and challenges related to them-is the Virkkulankylä retirement village concept now being devised and actualised in several locations around the country. The main actor behind Virkkulankylä is a small Finnish property-developing company and its managing director, a senior himself, who started planning an alternative housing model for ageing people in the early 2010s (Interview 1; see also Pirinen, 2016). At the time of this writing (autumn 2018), there are about ten ongoing Virkkulankylä building projects and a similar number of negotiations with various municipalities and cities in Finland about establishing Virkkulankylä villages. What is noteworthy about Virkkulankylä is that the organisational structure behind each village's operation varies from project to project. The property company is mostly responsible for developing the Virkkulankylä concept and managing each project, but the spatial planning, design and building work is done by different architectural and construction firms. The care services offered in each of the villages are provided either by municipalities or by private social service companies. The idea with Virkkulankyläs is that social activities in and around the villages are organised by members of the non-profit association Friends of Virkkula (Virkkulan Ystävät ry), which is founded in the context of each new village.

Similar to its international counterparts, the Virkkulankylä retirement village aims to integrate the housing and care of older people in a way that pays attention to communal living, active ageing and social interaction (Document 1). Virkkulankylä villages usually involve a care unit, but an important part of the village are the Virkkula Homes (Jalava et al., 2017: 39), which are targeted at the more independent and active residents who would also benefit from care services in the same premises. Hence, the Virkkulankylä concept correlates well with the idea of 'ageing-in-place' but does so in a way that adapts to the changing needs of residents (cf. Croucher, 2006). One idea is that Virkkulankylä villages would involve a mixture of residents and even intergenerational housing arrangements with carefully designed common areas to bring people together spontaneously (Document 1). This would be made possible by providing various housing tenure options for those moving to Virkkula Homes, including owner occupancies, rental apartments and social housing.

In general, the Virkkulankylä concept resembles many other international retirement village models in its goals to intermix housing, care and social activities (cf. Croucher, 2006; Howe et al., 2013; Scharlach et al., 2014). Moreover, it corresponds to the demand for new elderly care and housing solutions indicated in the Finnish policy documents and programmes introduced above (YM, 2013; STM, 2017). Nevertheless, there have been several practical challenges that have delayed the actual construction of the Virkkulankylä villages, and many of these problems are related to legal and bureaucratic obstacles that have emerged during the planning and implementation processes. In this analysis, Virkkulankylä is manifested mostly as a housing and building project and only secondly as a matter of social services and elderly care. In the Finnish Trade Register, the primary field of operation for the company behind the Virkkulankylä concept is reported as 
construction contracting, real estate and/or rental activities (Documents 2 and 3), and the actual elderly care and support services are executed by external parties. Hence, questions about the built environment and the disputes and problems concerning housing and design are central in realising the Virkkulankylä retirement villages.

Regarding the built environment, land use planning has been one issue that has especially caused problems at some of the Virkkulankylä sites. In the Siuntio municipality, for example, the suggested plan for the Virkkulankylä village (Document 4) received complaints because it was considered a contradiction of the local plan, so the location of the intended village was changed in order to avoid a heavy litigation process (Document 5). A new site has been zoned for the village (Document 6), but it is located further from the centre of Siuntio and thus further from public services. Another local dispute occurred in Kuusjärvi village in the municipality of Outokumpu. There, the municipal authorities did not support the ARA grant for the Virkkulankylä project, seeing no need for new senior housing solutions in the municipality (Interview 2). Hence, in Kuusjärvi only a separate extra-care housing unit has been built on the site of the planned Virkkulankylä, and the actual Virkkula Homes still await possible implementation. A similar situation prevails in Pori city where the municipality favoured the Virkkulankylä project, but the funding body ARA, the Virkkulankylä company and the service provider Mehiläinen could not agree on which functions the state subsidies should be allocated for. As a consequence, the Virkkulankylä company declined the ARA grant (Document 7; Interview 1), and there is now only a small extra-care housing unit in Pori managed by the large private social and health-care company Mehiläinen. The actual Virkkula Homes are projected to be built later with private money (Interview 2).

I was able to visit one newly built Virkkulankylä located in Reijola, Joensuu a few weeks after its opening in February 2018. The Virkkulankylä in Reijola is the first and thus far the only 'village' where Virkkula Homes and the care unit are in concurrent operation. In Reijola, there had not been any major problems with the land use planning, but the challenges were more related to the characteristics and architecture of the site and the concept design of the 'village'. For example, the facility was not promoted distinctly under the Virkkulankylä village concept but as an independent care unit run by the private Mehiläinen company (Document 8). Moreover, the appearance of the 'village' in Reijola was not particularly unique but rather similar to a normal extra-care housing estate for older people. It consisted of a three-storey building with some 40 dwelling rooms and three common areas for dining and interaction, one on each floor. The house was new and beautifully decorated, but the plot was quite small and the yard was not completed (field notes, 22 February 2018). The entrance and different departments in the building had electric doors and locks for safety and security reasons. The staff wore working clothes and carried control phones in their pockets, and the residents all had electric wristbands that worked as call buttons, keys and tracers. Hence, in many respects, the facility seemed more like an institutional care setting ( $c f$. Repo, 2018) than a community-based living environment. The residents can, however, bring their own furniture and ornaments to their rooms (Document 9), and in the separate Virkkula Homes the living is more independent as the apartments 
have their own kitchenettes and access to the backyard. Even though the building in Reijola does not accommodate many amenities apart from those related to housing and care, the surrounding neighbourhood has various external services such as a grocery store, library, pharmacy and a small cultural centre. In addition, the Friends of Virkkula are active in Reijola (Documents 10 and 11). Therefore, the Virkkulankylä in Reijola has the potential to support ageing people in living a more social and interactive life - provided that residents can first leave and visitors can enter through all the doors, locks, elevators and electric systems.

Despite the challenges, the actors behind Virkkulankylä remain relatively optimistic about their housing model. For example, a new Virkkulankylä village will be built in Kouvola as part of the annual Finnish House Fair in 2019, and the interviewees (2,3 and 4) see it as the first site to genuinely follow the original spirit of the Virkkulankylä concept. The House Fair organisers are interested in developing and promoting the alternative senior housing model, and the project has received a positive decision about a state-subsidised ARA grant (Document 12). According to the interviewees (2, 3 and 4$)$, another positive aspect is that the processes of land acquisition and planning in some municipalities have proceeded more smoothly than in other locations. One challenge not raised in the interviews, however, is internal and relates to the incompleteness of the actual Virkkulankylä concept. The organisational structure of each Virkkulankylä changes from one municipality to another, and the accommodation options, services provided and social activities vary considerably between villages. This variance indicates that the Virkkulankylä concept is still in progress. Nevertheless, this incompleteness also represents a flexibility in arranging housing and care services for ageing adults. Therefore, it can also be seen as an advantage when creating new and alternative housing solutions for older people.

\section{A spatio-legal interpretation of the intermediate housing-with-care solutions: potentials and barriers}

The development of intermediate housing-with-care solutions for ageing people, including retirement villages and communities, can be understood as one step in the deinstitutionalisation of elderly care services and the ageing-in-place policies that are widespread in many countries. The key potential of retirement villages is that their operation is based on community-oriented living rather than simply on institutional residential care or on isolated home care. Promoted as comprehensive and integrated living options, retirement villages are positioned between the traditional domestic and institutional care environments. Seen in a positive light, they can combine the good sides of both categories. For example, living in a retirement village fosters the independence of residents while simultaneously providing safe, age-friendly and active living environments for ageing people ( $c f$. Croucher, 2006; Scharlach et al., 2014). Unsurprisingly, retirement villages, communities and other intermediate housing-with-care solutions are receiving more international recognition and attention in new national contexts, such as in Finland.

In practice, however, integrating housing and care in a flexible manner can be problematic due to a number of legislative and bureaucratic obstacles that pose challenges for implementing new senior housing models. As the key result of the 
preceding legal and policy analysis of Finnish legislation and the case study of the Virkkulankylä village concept, I have identified three major spatio-legal barriers to the development of intermediate housing-with-care forms for ageing people. These barriers are (a) the polarised division between the fields of elderly care and housing in both law and practice, (b) the prevalence of the so-called 'local law' in providing and governing services and spatial planning for older people, and (c) the inflexible statutory funding system regarding subsidies for alternative senior living solutions.

Firstly, the analysis of Finnish legislation demonstrates that elderly care and housing are still polarised topics, and their division is based on sectoral thinking. Although the law promotes service integrated housing for people who need special support (Social Care Act 1301/2014), it shows a narrow understanding of the spatialities of such facilities. The intermediate and alternative housing forms of older people are not directly recognised in Finnish legislation even though their demand has been acknowledged in some policy documents. Moreover, land use planning and zoning issues are only partly taken into account in discussions concerning elderly care services even though they form the basis for the built environment's spatial structure and therefore are important when creating new senior housing solutions (see also de Lisle 1998; Rosenthal, 2009; Pynoos, 2018). Although Finnish planning law recognises the needs of elderly people at least at a general level (Land Use and Building Act 132/1999), the issues related to age-friendly environments and building accessibility are treated in a mostly technical manner. There are also international examples of how overly strict planning regulations, such as restrictive zoning and land use classes, may negatively affect the development of alternative housing and care settings for older people (de Lisle 1998; Liebig et al., 2006; King, 2011). Hence, the polarised approaches to the built environment and elderly care services make the development of retirement villages and other intermediate housing-with-care settings ambiguous and difficult.

Secondly, the special position of the 'local law' is noteworthy when studying housing and care services for elderly people from a spatio-legal perspective. Local law refers to those various sub-legal regulations and enforcement practices that take place at a community level (Valverde, 2012). Reliance on local practices does not have to be a barrier to implementing intermediate housing-with-care solutions, but on the contrary, local law may provide better participation opportunities and bring the decision-making process closer to the citizens. Nevertheless, much depends on how local authorities use their administrative and bureaucratic power. The analysis here shows that local and municipal authorities, at least in Finland, have a strong role in managing and providing care services for older people, and they also determine the details of local land use plans and give statements that affect state subsidies for social housing. Hence, municipalities can be seen as gatekeepers of the creation of retirement villages and other similar kinds of housing-with-care solutions for ageing people. The same conclusion has been pointed out by Rosenthal (2009), who says that local authorities can enhance the age-friendliness of the built environment by, for example, eliminating regulatory barriers to senior housing. On the other hand, local governance and bureaucracy may complicate the building of retirement villages, as has been the case with some of the Virkkulankylä sites (Siuntio, Kuusjärvi) studied in this article. In Finland, the monopoly of the municipalities, especially over land use planning, 
confers much power to local authorities in guiding and steering the development of new housing solutions.

Thirdly, one central barrier, or rather a disincentive, to the development of retirement villages is the lack of a clear statutory funding system that would support the provision of more alternative and innovative housing models for ageing people. As discussed in the analysis section, the state subsidies in Finland (ARA grants) targeted for the rental housing of special groups are still quite rigid and inflexible in terms of intermediate housing-with-care solutions for older people. In many ways, private money is a more adaptable way to finance new housing developments. Senior housing and care markets are growing businesses (see e.g. Anttonen and Häikiö, 2011; Nummelin, 2005) and therefore also intermediate housing-with-care solutions are becoming appealing to private property investors and large social and health-care companies. Consequently, also large multinational companies can have direct or indirect access to the state subsidies, which, seen critically, may channel benefits away from the needs of older people to the company shareholders (Hoppania et al., 2016). Although the privatisation of elderly care may improve the quality of certain service aspects (see Stolt et al., 2011), it can also lead to the commodification and marketisation of care which are criticised by many scholars (e.g. Cutchin, 2007; Green and Lawson, 2011; Schwiter et al., 2018). Moreover, admission to private care residences and retirement communities can be expensive, which hinders equal access to the new housing alternatives. Some new financing and tenure systems have been developed in order to make retirement villages and other housing-with-care forms available also for older adults on less income, including, for instance, reversed mortgage, housing co-operatives and mixed-tenure estates (Evans, 2009b; Jalava et al., 2017), but also those systems have their own challenges (see Evans, 2009b; Petersen et al., 2017). All these ambiguities related to retirement villages indicate that some caution is needed when supporting and funding new housing-with-care solutions for senior citizens, especially if their development is based more on market logics than on the actual care needs of ageing people.

In addition to the spatio-legal barriers and possibilities described above, there are other factors that affect the development of retirement villages. Some factors are internal, as the case of the Virkkulankylä concept demonstrates. When evaluating the possibilities of retirement villages, it is important to consider how the management, functions, contents and activities of the villages are organised, and how community residents can take part in decision-making (see also Liddle et al., 2014). The Virkkulankylä village concept is incomplete and evolving, and thus not all of these questions have been answered yet. Notwithstanding this last point, the position of retirement villages as sitting in-between the categories of housing and care services as well as homes and institutions has the potential for more comprehensive living solutions where the physical, social and experiential needs of ageing people are, at least in principal, met and satisfied. Nevertheless, this 'in-betweenness' can also be a problem because it causes many legal, technical and bureaucratic challenges, as demonstrated in this article. To overcome these challenges, more flexibility is needed in the regulatory systems and administrative practices that govern the development of housing and care services for elderly people. The question of the living conditions of older people should be seen as a horizontal issue rather than a sectoral one. Better collaboration among the different 
actors in the field of elderly services is needed at national and local levels, as well as between the housing and care sectors. Adequate funding is also important, but even more significant is understanding the actual needs and demands of residents living in retirement villages and communities.

\section{Concluding remarks}

New housing-with-care solutions for older people are both constituted by and constitutive of complex legal, spatial and social relations that work at the macro-level and micro-level of society ( $c f$. Milligan and Wiles, 2010). The spatio-legal approach employed in this article is useful when studying such relations as it recognises the legislative and spatial processes behind the new and integrated senior housing and care settings. The law and the space should not be understood as fixed entities, but rather, they and their relational interpretations involve ruptures and inconsistencies (Massey, 2005; Rannila, 2018). Therefore, the spatio-legal approach is particularly valuable when analysing retirement villages and other intermediate housing-with-care solutions that fall between various categories of law and practices and are thus only gradually finding their place in the wider landscapes of elderly care.

If appropriately implemented, retirement villages and other similar housing-with-care facilities can become settings where the physical, social and experiential sides of older people's lives are appreciated and combined in a comprehensive manner. However, this study has shown that even though the ideal of retirement villages is to offer an all-inclusive living environment for older adults, this can be difficult in practice because of the many legal and bureaucratic obstacles they face due to their ambiguous position 'in-between' different categories. As discussed in this paper, the polarisation between elderly care and housing sectors, the shortcomings of local practices (such as unfavourable land use planning) and inflexible funding systems are among the spatio-legal barriers and disincentives that affect the development of retirement villages and other intermediate housing-with-care options. It is also necessary to exercise caution when studying, promoting or implementing new housing models for ageing people, as their uncritical adoption may lead to other problems such as the commodification of care or unequal access to services. Alternative housing-with-care solutions are not necessarily permanent living options for later life nor are they always available for older adults with low incomes. Nevertheless, new living solutions for older people such as retirement villages help to diversify the spaces and places of ageing and care.

This article has demonstrated how geographical and political settings matter when establishing new housing-with-care opportunities for senior citizens. The possibilities and problems that the implementation of a retirement village concept have met in Finland offer a good perspective on ambiguities related to the adoption of the alternative senior housing solutions in new national and local contexts. Hence, the development of intermediate housing-with-care solutions for older people is a sensitive subject that requires more critical and applied research outside Anglophone countries. The spatial-legal approach introduced in this paper hopefully provides valuable new perspectives and methodological openings for scholars 
and professionals working with questions concerning the housing, care and wellbeing of ageing people both nationally and internationally.

\section{Notes}

1 All the English translations of the Finnish acts and decrees in this article are unofficial and extracted from finlex.fi, or if not available there, translated by the author herself.

2 HE 160/2012: Government Proposal to the Parliament for an Act on Supporting the Functional Capacity of the Older Population and on Social and Health Services for Older Persons and for an Act on the Repeal of the Section 20 of the Health Care Act.

HE 240/2014: Government Proposal to the Parliament for an Act on the Amendment of the Act on Supporting the Functional Capacity of the Older Population and on Social and Health Services for Older Persons.

Acknowledgements. I would like to thank the anonymous reviewers, as well as my colleagues in our research project, Jani Vuolteenaho, Päivi Rannila and Virve Repo, for their comments and help with this paper.

Financial support. This work was supported by the Academy of Finland (grant number 308616).

Ethical standards. This study meets the ethical guidelines of the Finnish National Board of Research Integrity (TENK) and is conducted in adherence to the Finnish law.

\section{References}

Andrews GJ and Phillips DR (eds) (2004) Ageing and Place: Perspectives, Policy, Practice. Abingdon, UK: Routledge.

Anttonen A and Häikiö L (2011) Care 'going market': Finnish elderly-care transition. Nordic Journal of Social Research 2, 1-21.

ARA (2017) Rakennuttamis- ja suunnitteluopas [The Building and Design Guide]. Helsinki: Housing Finance and Development Centre of Finland. Available at http://www.ara.fi/fi-FI/Tietopankki/Oppaat/ Rakennuttamis_ja_suunnitteluopas(40242).

Bernard M, Bartlam B, Sim J and Biggs S (2007) Housing and care for older people: life in an English purpose-built retirement village. Ageing \& Society 27, 555-578.

Bernard M, Liddle J, Bartlam B, Scharf T and Sim J (2012) Then and now: evolving community in the context of a retirement village. Ageing \& Society 32, 103-129.

Bowen G (2009) Document analysis as a qualitative research method. Qualitative Research Journal 9, 27-40.

Braverman I, Blomley N, Delaney D and Kedar A (eds) (2014) The Expanding Spaces of Law: A Timely Legal Geography. Stanford, CA: Stanford University Press.

Chrysikou E, Tzikari C and Buhalis D (2018) Architectural hybrids for living across the lifespan: lessons from dementia. Service Industries Journal 38, 4-26.

Cope M (2010) Coding qualitative data. In Hay I (ed.), Qualitative Research Methods in Human Geography, 3rd Edn. Melbourne: Oxford University Press, pp. 281-294.

Croucher K (2006) Making the Case for Retirement Villages. York, UK: Joseph Rowntree Foundation.

Croucher K, Hicks L and Jackson K (2006) Housing with Care for Later Life: A Literature Review. York, UK: Joseph Rowntree Foundation.

Cutchin MP (2007) Therapeutic landscapes for older people: care with commodification, liminality, and ambiguity. In Williams A (ed.), Therapeutic Landscapes. Aldershot, UK: Ashgate, pp. 181-198.

Delaney D (2010) Nomospheric Investigations: The Spatial, the Legal and the Pragmatics of World-making. Abingdon, UK: Routledge.

de Lisle VM (1998) Senior housing: zoning for the future. Probate \& Property 12, March, 33-37.

Evans S (2009a) Community and Ageing: Maintaining Quality of Life in Housing with Care Settings. Bristol, UK: Policy Press. 
Evans S (2009b) 'That lot up there and us down here': social interaction and a sense of community in a mixed tenure UK retirement village. Ageing \& Society 29, 199-216.

Frank J (2001) How long can I stay? The dilemma of aging in place in assisted living. Journal of Housing for the Elderly 15, 5-30.

Glass AP (2014) Innovative seniors housing and care models: what can we learn from the Netherlands. Social Housing \& Care Journal 22, 74-81.

Green M and Lawson V (2011) Recentring care: interrogating the commodification of care. Social \& Cultural Geography 12, 639-654.

Haeusermann T (2018) The dementia village: between community and society. In Krause F and Boldt J (eds), Care in Healthcare: Reflections on Theory and Practice. Cham, Switzerland: Palgrave Macmillan, pp. 135-167.

Holland C, Boukouvalas A, Wallis S, Clarkesmith D, Cooke R, Liddell L and Kay A (2017) Transition from community dwelling to retirement village in older adults: cognitive functioning and psychological health outcomes. Ageing \& Society 37, 1499-1526.

Hoppania H-K (2015) Care as a Site of Political Struggle. Publications of the Department of Political and Economic Studies. Helsinki: Unigrafia.

Hoppania H-K, Karsio O, Näre L, Olakivi A, Sointu L, Vaittinen T and Zechner M (2016) Hoivan arvoiset: Vaiva yhteiskunnan ytimessä [Worthy of Care: Care Needs in the Core of the Society]. Helsinki: Gaudeamus.

Howe A, Jones A and Tilse C (2013) What's in a name? Similarities and differences in international terms and meanings for older people's housing with services. Ageing \& Society 33, 547-578.

Hytönen J (2016) The problematic relationship of communicative planning theory and the Finnish legal culture. Planning Theory 15, 223-238.

Jalava J, Lahtinen H, Tyvimaa T, Vuorela M and Arolinna S (2017) Ikääntyneiden asumisratkaisujen tarve ja toteutus [Demand for Housing Solutions for the Older Population and How to Meet the Demand]. The Ministry of Environment: Helsinki. Available at http://urn.fi/URN:ISBN:978-952-114710-4.

Jolanki O and Kröger T (2015) Onko vanhalla vara valita? Vanhojen ihmisten uudet asumisvaihtoehdot [Can old people afford to choose? The new living alternatives of older people]. In Häkli J, Vilkko R and Vähäkylä L (eds), Kaikki kotona? Asumisen uudet tuulet. Helsinki: Gaudeamus, pp. 82-92.

Jylhä M (2015) Vanhuus pitenee, hoiva vähenee? [Lives become longer, care becomes less?]. Talous \& Yhteiskunta 2015, 40-45.

King N (2011) Planning Use Classes and Extra Care Housing. Viewpoint 20. London: Housing Learning and Improvement Network. Available at https://www.housinglin.org.uk/_assets/Resources/Housing/ Support_materials/Viewpoints/Viewpoint_20_Planning_Use_Classes.pdf.

Kröger T, Van Aerschot L and Puthenparambil JB (2018) Hoivatyö muutoksessa. Suomalainen vanhustyö pohjoismaisessa vertailussa [Care Work in Transition: Finnish Elderly Care in a Nordic Comparison]. YFI Publications 6. Jyväskylä: University of Jyväskylä.

Laws G (1993) 'The land of old age': society's changing attitudes toward urban built environments for elderly people. Annals of the Association of American Geographers 83, 672-693.

Laws G (1995) Embodiment and emplacement: identities, representation and landscape in Sun City retirement communities. International Journal of Aging and Human Development 40, 253-280.

Liddle J, Scharf T, Bartlam B, Bernard M and Sim J (2014) Exploring the age-friendliness of purposebuilt retirement communities: evidence from England. Ageing \& Society 34, 1601-1629.

Liebig PS, Koenig T and Pynoos J (2006) Zoning, accessory dwelling units and family caregiving. Journal of Aging and Social Policy 18, 155-172.

Massey D (2005) For Space. London: Sage.

Milligan C (2000) 'Bearing the burden': towards a restructured geography of caring. Area 32, 49-58.

Milligan C (2009) There's No Place Like Home: Place and Care in an Ageing Society. Abingdon, UK: Ashgate.

Milligan C and Wiles J (2010) Landscapes of care. Progress in Human Geography 34, 736-754.

Mäki-Petäjä-Leinonen A and Karvonen-Kälkäjä A (2017) Vanhuusoikeuden perusteet [The Basics of Elder Law]. Helsinki: Alma Talent.

Moisio S (2012) Valtio, alue, politiikka. Suomen tilasuhteiden sääntely toisesta maailmansodasta nykypäivään [State, Region, Politics: The Regulation of Spatial Structures in Finland from the Second World War up to the Present]. Tampere, Finland: Vastapaino. 
Nummelin J (2005) Business potential in senior services. International Journal of Strategic Property Management 9, 191-200.

Paasivaara L (2002) Suomalaisen vanhusten hoitotyön muotoutuminen monitasotarkastelussa 1930-luvulta 2000-luvulle [Goals and Actual Practice. Multi-level Analysis of the Evolution of Finnish Geriatric Nursing from the 1930s till the 2000s]. Oulu, Finland: Oulu University Press.

Parliamentary Ombudsman (2009) Ympärivuorokautisessa hoidossa olevien vanhusten perus- ja ihmisoikeuksien turvaaminen [Securing the Basic and Human Rights of Older People in Round-the-clock Care]. Helsinki: Parliamentary Ombudsman of Finland. Available at http://www.eduskunta.fi/eoaratkaisut/eoae $+213 / 2009$.

Petersen M, Tilse C and Cockburn T (2017) Living in a retirement village: choice, contracts and constraints. Journal of Housing for the Elderly 31, 229-242.

Phoebe SL, Koenig T and Pynoos J (2006) Zoning, accessory dwelling units, and family caregiving. Journal of Aging \& Social Policy 18, 155-172.

Pirinen A (2016) Housing concepts for and by the elderly: from subjects of design to a design resource. Journal of Housing for the Elderly 30, 412-429.

Pynoos J (2018) The future of housing for the elderly: four strategies that can make a difference. Public Policy \& Aging Report 28, 35-38.

Pynoos J, Nishita C, Cicero C and Caraviello R (2008) Aging in place, housing, and the law. Elder Law Journal 16, 77-105.

Rakennustieto (2013) Vanhusten palveluasuminen [Service Integrated Housing for Older People]. RT 93-11134. Helsinki: Rakennustietosäätiö.

Rannila P (2018) Relationality of the law: on the legal collisions in the Finnish planning and land use practices. Journal of Planning Education and Research. Available online doi:10.1177/0739456X18785443.

Repo V (2018) Spatial control and care in Finnish nursing homes. Area. Available online doi:10.1111/ area.12443.

Rosenthal L (2009) The role of local government: land-use controls and aging-friendliness. Generations 33, $2,18-25$.

Scharlach A, Davitt J, Lehning A, Greenfield E and Graham C (2014) Does the village model help to foster age-friendly communities? Journal of Aging and Social Policy 26, 181-196.

Schwiter K, Berndt C and Truong J (2018) Neoliberal austerity and the marketisation of elderly care. Social \& Cultural Geography 19, 379-399.

STM (2016) Improved Home Care for Older Persons and Enhanced Informal Care in All Age Groups. Government Key Project 2016-2018. Helsinki: Ministry of Social Affairs and Health. Available at https://stm.fi/en/improved-home-care-for-older-persons-and-enhanced-support-for-all-aged-informalcarers.

STM (2017) Quality Recommendation to Guarantee a Good Quality of Life and Improved Services for Older Persons 2017-2019. Helsinki: Ministry of Social Affairs and Health. Available at http://urn.fi/URN: ISBN:978-952-00-3906-6.

Stolt R, Blomqvist P and Winblad U (2011) Privatization of social services: quality differences in Swedish elderly care. Social Science \& Medicine 72, 560-567.

Streib GF (2002) An introduction to retirement communities. Research on Aging 24, 3-9.

Svendborg (2018) Bryghuset Svenborg Demensby. Svenborg Kommune. Available at https://www.svendborg. $\mathrm{dk} /$ sites/default/files/demensby_folder.pdf.

THL (2011) Yksityiset sosiaalipalvelut 2010 [Private Social Services 2010]. Statistical Report 25/2011. Helsinki: National Institute for Health and Welfare. Available at http://urn.fi/URN:NBN:fife201205085520.

THL (2017) Kotihoito ja sosiaalihuollon laitos- ja asumispalvelut 2016 [Home Care, Institutional Care and Housing Care Services in Finnish Social Welfare 2016]. Statistical Report 42/2017. Helsinki: National Institute for Health and Welfare. Available at http://urn.fi/URN:NBN:fi-fe2017112050792.

Townshend IJ (2002) Age-segregated and gated retirement communities in the third age: the differential contribution of place - community to self-actualization. Environment and Planning B: Planning and Design 29, 371-396.

Valverde M (2012) Everyday Law on the Street: City Governance in an Age of Diversity. Chicago, IL: The University of Chicago Press. 
Valvira (2016) Kaltoinkohtelu ympärivuorokautisissa vanhustenhuollon yksiköissä työntekijöiden havainnoimana [Mistreatments in the Round-the-clock Elderly Care Units Observed by the Staff]. Helsinki: Valvira, National Supervisory Authority for Welfare and Health. Available at https://www.valvira.fi/-/kal toinkohtelu-ymparivuorokautisissa-vanhustenhuollon-yksikoissa-tyontekijoiden-havainnoimana.

Verma I, Kurkela T, Sanaksenaho P, Suominen J, Taegen J and Vauramo E (2017) Palvelukortteli. Konseptin kuvaus ja soveltaminen erilaisiin taajamiin [Service Block: The Concept and its Application to Different Types of Population Centres]. Helsinki: Ministry of Environment. Available at http://urn. fi/URN:ISBN:978-952-11-4725-8.

Wiles JL, Leibing A, Guberman N, Reeve J and Allen RES (2011) The meaning of 'aging in place' to older people. The Gerontologist 52, 357-366.

Xia B, Zuo J, Skitmore M, Chen Q and Rarasati A (2015) Sustainable retirement village for older people: a case study in Brisbane, Australia. International Journal of Strategic Property Management 19, 149-158.

YM (2013) Housing Development Programme for the Older Population 2013-2017. Helsinki: Ministry of Environment. Available at https://www.ymparisto.fi/download/noname/\%7B8BEDFDB9-CAE9-443A95F4-4F38013937E8\%7D/97629.

YM (2017) Government Decision on Finland's National Land Use Guidelines. Helsinki: Ministry of Environment. Available at https://www.ymparisto.fi/download/noname/\%7BC8DAA05E-FBC8-490EA805-37BCE01A1E43\%7D/138177.

\section{Appendix}

\section{Virkkulankylä: interviews and documents}

Interview 1: By phone, 17 April 2018.

Interview 2: Outokumpu, 22 February 2018.

Interview 3: Joensuu, 23 February 2018.

Inteview 4: Pori, 11 April 2018.

Document 1: Weman T (2013) Virkkulan seniorikylä. Virikkeellisen yhteisöasumisen konsepti ikääntyville [The Virkkula Senior Village: An Active Community Living Concept for Ageing People]. Tampere: Tampereen Teknillinen yliopisto. Available at http://URN.fi/URN:NBN:fi:tty-201609294566.

Document 2: Virkkulankylä Oy. Kaupparekisteriote [Extract from the Trade Register], registered 11 June 2014, Finnish Patent and Registration Office, Helsinki.

Document 3: Kuusikkoaho Oy. Kaupparekisteriote [Extract from the Trade Register], field of operation registered 21 March 2014, Finnish Patent and Registration Office, Helsinki.

Document 4: Virkkulan Seniorikylän asemakaavan muutos, luonnos [The local detailed plan of Virkkula retirement village, draft], 15 June 2015, Siuntio municipality.

Document 5: Tekninen lautakunta, kokouspöytäkirja [Technical board, report of a meeting], 14 March $2017, \$ 39$, Siuntio municipality.

Document 6: Palonummen Virkkulan seniorikylän asemakaava ja asemakaavan muutos, ehdotus [The local detailed plan of Virkkula retirement village in Palonummi, proposal], 13 October 2017, Siuntio municipality.

Document 7: ARA. Ehdollinen varaus erityisryhmien investointiavustuksen myöntämiseen... 36650/ 321/17 [Conditional reservation for an investment grant...], Virkkulankylä Oy, Porin Virkkula, 3 February 2017, The Housing Finance and Development Centre of Finland, Helsinki.

Document 8: Mainiokoti Elli, Reijola, a marketing brochure, accessed 22 February 2018, Mehiläinen Hoivapalvelut Oy, Joensuu.

Document 9: Mainiokoti Elli, Reijola. Sosiaalipalvelujen omavalvontasuunnitelma [Self-monitoring plan for the social services], 21 August 2017, Mehiläinen Hoivapalvelut Oy, Joensuu.

Document 10: Reijolan Virkkulan Ystävät ry. Yhdistysrekisteriote [Extract from the Register of Associations], registered 1 February 2018, Finnish Patent and Registration Office, Helsinki.

Document 11: Reijolan Virkkulan Ystävät ry. Yhdistyksen säännöt [Constitution of an Association], 1 February 2018, Finnish Patent and Registration Office, Helsinki. 
Document 12: ARA. Ehdollinen varaus erityisryhmien investointiavustuksen myöntämiseen... 36973/ 321/18 [Conditional reservation for an investment grant...], Virkkulankylä Oy, Kouvolan Virkkula, 31 January 2018, The Housing Finance and Development Centre of Finland, Helsinki.

Cite this article: Lundman R (2020). A spatio-legal approach to the intermediate housing-with-care solutions for older people: exploring the adoption of a retirement village concept in Finland. Ageing \& Society 40, 1956-1977. https://doi.org/10.1017/S0144686X19000412 